\title{
Use of TOPSIS Method for Assessing of Good Governance in European Union Countries
}

\section{Eva Ardielli ${ }^{1}$}

\begin{abstract}
Good Governance presents the contemporary trend of managing public affairs worldwide. This concept is promoting the basic elements of subsidiarity, participation, and democracy in modern public administration. Presented article is focused on the evaluation of Good Governance development in the European Union countries in the long-term, in the period 2007-2017. The evaluation is based on the application of multiple criteria decision-making methods, concrete The Technique for Order Preference by Similarity to Ideal Solution. The original data used in the research were the values of Worldwide Governance Indicators monitored and processed by the World Bank. The article presents a complete assessment of European Union countries according to the level of Good Governance. There are identified countries that have been successful in this area in the long-term, in particular the Nordic countries - Finland, Sweden and Denmark. On the contrary, there are countries that show greater shortcomings in terms of Good Governance as Romania, Bulgaria or Greece. The European Union countries were also grouped into clusters and the overview of rankings of individual countries for the period 2007-2017 was completed.
\end{abstract}

Key words: European Union countries; evaluation; good governance; governance indicators; MCDM; TOPSIS

\section{JEL Classification: H11, H83}

Received: 29 March 2019/Accepted: 16 August 2019/Sent for Publication: 9 September 2019

\section{Introduction}

The requirement for the provision of better and more accountable public services to the citizens and the promotion of sustainable socio-economic development is the basic issue of contemporary public administration in both the developed and developing countries (Kooiman, 2003). The basic concept of modern and properly functioning public administration leading to these targets is driven by Good Governance principles and Good Governance itself is often defined through these individual components (principles), see Potěšil (2008). The main characteristics of Good Governance are generally referred to as lawfulness, fairness, timeliness, predictability, persuasiveness, adequacy, collaboration, accountability, openness, and friendliness.

\footnotetext{
${ }^{1}$ VŠB - Technical University of Ostrava, Department of Public Economics, Sokolská 33, Ostrava, Czech Republic, eva.ardielli@vsb.cz
} 
As specified by Klenk and Nullmeier (2004) or Zanger (2000), Good Governance is the designation for high-quality and properly functioning public administration with an integrated element of subsidiarity, allowing for the participation of the citizens and respecting democratic values and the rules of the contemporary modern state.

The successful implementation of Good Governance concept in the individual countries indices the quality of governance and overall maturity of public administration in the state. However, as stated by Agere (2000), Good Governance is an ideal state of government, which is as a whole difficult to achieve.

The evolution of the concept of Good Governance began in the 20th century, mainly related with the debt crises in developing countries in the 1980s and remains at the forefront since the mid of 90s of the 20th century (Jann, Röber, and Wollmann; 2006). The role of the government started to grow in importance as a significant factor in socioeconomic development. The concept of Good Governance became a guide for developing countries, and the attention shifted to governance reforms. The governmental reforms in recipient developing countries became a condition for the allocation of aid by international donor institutions (Acemoglu and Robinson 2010). Good Governance is primarily presented by the World Bank as a requirement of national states to facilitate successfully economic and administrative reforming processes (Haldenwang, 2004).

The aim of the presented article is to evaluate Good Governance development in the European Union (EU) countries by the usage of The Technique for Order Preference by Similarity to Ideal Solution (TOPSIS) in the period 2007-2017. The assessment is based on data, collected by the World Bank (World Bank, 2018), concretely on six aggregated indicators - Worldwide Governance Indicators (WGI): quality of democracy, political stability, and absence of violence, governance effectiveness, regulatory burden, quality of the rule of law and control of corruption.

The original approach of this assessment is the application of TOPSIS method, which, according to the achieved quality of public administration in the area of Good Governance, determines the ranking of EU countries in individual years of the monitored period 2007 - 2017. In the frequent case, in scientific work and comparisons, the evaluation of Good Governance in the countries with usage of WGI is based on the comparison of the composite index of Good Governance, similarly to Žák (2005) or Ardielli and Halásková (2015a) which is constructed on the basis of the above mentioned aggregate indicators as the arithmetical average. Another approach is to make the sum of Governance indicators by adding up the scores of all of these six items, to get the integrated indicators in a scale of +15 to -15 , see Madzova, Sajnoski, and Davcev (2013). Government performance in EU countries based partly on selected WGI is also evaluated in the study of the European Commission, see European Commission (2018). There are used and compared in EU countries the values of the Voice and accountability index, Control of corruption index, Regulatory quality index and Rule of law index in the selected year 2013. The ranking of EU countries was performed for every index separately.

No one of these approaches were used in the present article. In the presented article, the evaluation of Good Governance development in EU countries was performed based on the application of Multiple-criteria decision-making (MCDM) method - TOPSIS method. TOPSIS appears to be an appropriate solution for determining the ranking of EU 
countries, using six aggregate indicators of the World Bank database, as it is not a mere average nor a mere sum of these values.

The paper is organized as follows. In the Introduction, there is presented a short overview of the issue of Good Governance. In the theoretical part, there is summarized the theoretical basis of Good Governance concept, provided the literature review, and described the evolution of governance indicators. In the methodological part are presented the methods used and data sources. In the empirical part of the article are summarized the results of Good Governance assessment in the EU countries and discussed the achieved results. Finally, summarizations and concluding remarks are made in the last section.

\section{Literature review}

The term "Good Governance" has been extensively used in the international environment during the last two decades. This concept incorporates a variety of principles and is described in a number of important documents with international scope (Klimovský, 2010). However, Good Governance is not legislatively defined at the national or international level. Comprehensive look on the issue of Good Governance is available in the "Council of Europe (COE) Recommendation on good administration" from 2007, see Council of Europe (2007), and its Supplement. This document aims to define the basic right to good administration and to facilitate its effective implementation in practice. Good Governance is the aim of the COE countries, which should be achieved and maintained. It covers the reflection of quality, clear, transparent, and understandable legislation, meets the principle of participatory democracy and is based on the protection of the rights of individuals (Potěšil, 2008). The "12 Principles of Good Governance" were also enshrined in the "Strategy on Innovation and Good Governance" at a local level, endorsed by a decision of the Committee of Ministers of the COE in 2008. They cover issues such as ethical conduct, rule of law, efficiency and effectiveness, transparency, sound financial management, and accountability. The basic elements of the concept include:

- effective, impartial and speedy trial,

- transparent public institutions,

- responsibility for decision-making by public officials,

- transfer resources and decisions from the centre to the local level,

- meaningful participation of citizens in the negotiation of public policies,

- universal protection of human rights,

- non-discriminatory laws.

It can be summed up, that the issue of Good Governance means finding the optimal system of governance that is effective and leads to long-term economic prosperity and social balance, which is critical to maintaining trust and legitimacy of the democratic systems of government. As well as stated by Keping (2018), Good Governance is the active and productive cooperation between the state and citizens, and the key to its success lies in the powers participating in political administration. 
The very important question is about the interdependence of Good Governance and socio-economic development (Haldenwang, 2004 or Agere, 2000). Governance improvement and country development are considered to be related issues. Many authors discuss the relationship of the implementation of governance reforms and rapid economic and social development, see Pillay (2016). Good Governance is discussed as the key factor of sustained growth in developed countries, see Agere (2000) and one of the most important elements in the fight for poverty reduction and equitable economic growth in developing countries, see Grindle (2004). As stated by the World Bank (1992), Good Governance concept is synonymous with sound development management. However, the enforcement of governmental reforms in developing countries by donor institutions, as International Monetary Fund or the World Bank, is considered ineffective and in reality not supporting policy changes (Abdelatif, 2003). Andrews (2008: 401) claims that given the evidence of multiple states, the idea of a one-best-way model seems to be problematic.

However, the individual elements of Good Governance are usually the key guideline when applying the modernisation process of governments. Surely not only Good Governance concept but also the individual historical, political, and economic conditions of each country have to be taken into account when reforms are prioritised (Grindle, 2007).

\section{Good Governance indicators}

Good Governance is theoretically and practically often conceived with the application of so-called Good Governance indicators. The country efforts are examined and evaluated based on the implementation of governance reforms, and the results are dependent on the improvement of the governance indicators. There are many approaches to assessing Good Governance, using different indicators evolving during the time. Their use in country evaluation is generally defended. However, some authors have questioned their explanatory power, see Andrews (2008) or Sundaram (2018).

\section{Evolution of Governance Indicators}

Because Good Governance concept has a relatively short history, there is a large number of projects dedicated to the modern measuring and monitoring of governance performance. The main reasons for these initiatives are the efforts to combat corruption (Jones and Kettl 2003). The outputs of these projects cover a wide portfolio of governance indicators. The beginnings of the application of governance indicators are in the 80 s of the 20th century when the qualitative case studies were published, emphasizing the importance of governance for socio-economic development, see North (1991). The main sponsor of these research projects were international organizations such as the United States Agency for International Development (USAID), International Monetary Fund, World Bank, United Nations, or EU.

Approaches to evaluating individual aspects of the governance are focusing mainly on expert assessment panels that enable comparisons among countries using a variety of indicators. The pioneers of this type of projects became private consulting firms already in the late $70 \mathrm{~s}$ and $80 \mathrm{~s}$ of the 20th century. In academic research, the data for assessment of governance began to be used in recent years, e.g., Clague et al. (1999). Parallel to these commercial activities, as documented by Potůček et al. (2007), gradually began to 
be promoted non-profit and academic projects of expert measurement of governance. The most famous is the "Corruption Perception Index of Transparency International". Other projects dealing with the evaluation of governance are e.g. Studies of the World Bank "World Business Environment Survey", an investigation of the University of the United Nations' "World Governance Survey" or the "Transformation Index" by Bertelsmann Foundation and "Global Governance Initiative" of the World Economic Forum, see Court and Hyden (2003), or Charron, Dijkstra and Lapuente (2015) developed the European Quality of Government Index (EQI). It is based on survey data on corruption and governance in the EU regions in 2010 and 2013. A very important contribution to the development of Good Governance indicators was a project of the World Bank "Institute Aggregate Governance Indicators", see UNPACS (2018). The benefit of indicators of Good Governance lies primarily in the fact that they highlighted the key role of Good Governance for successful socio-economic development.

\section{Measuring of Governance Performance by the World Bank}

Democracy, ethics, rule of law and transparency are key ingredients of effective government and public administration (Andrews, 2008) or (Ewaldt, 2001:9-11). The concept of Good Governance is very much inter-linked with these institutionalised values, see Agere (2000).

The World Bank has been collecting data about Good Governance for the broad international comparison since 1996, and currently, they have been monitored annually. It processes indicators of governance for 215 economies of the world, closer UNPACS (2018). There are used over 100 indicators as source data. These data sources are rescaled and combined to create the six aggregate indicators using a statistical methodology known as an unobserved components model. A key feature of the methodology is that it generates margins of error for each governance estimate. These margins of error need to be taken into account when making comparisons across countries and over time, see (Kaufmann et al., 2010).

Good Governance is then monitored on the basis of six aggregate indicators WGI Voice and Accountability, Political Stability and Absence of Violence, Government Effectiveness, Regulatory Quality, Rule of Law and Control of Corruption. These aggregate indicators combine the views of a large number of enterprise, citizen, and expert survey respondents in industrial and developing countries. They are based on over 30 individual data sources produced by a variety of survey institutes, think tanks, nongovernmental organizations, international organizations, and private sector firms. The WGI is a research dataset initiated by Daniel Kaufmann (Natural Resource Governance Institute and Brookings Institution) and Aart Kraay (World Bank Development Research Group) in 1999, see (World Bank, 2018). The World Bank is claiming a strong correlation between governance indicators and economic performance. The six composite WGI measures are useful as a tool for broad cross-country comparisons and for evaluating broad trends over time.

\section{Methodology}

In this paper, the issue of assessing Good Governance in EU countries is addressed through the application of MCDM methods. The theory of multicriterial analysis of 
variants deals with the problems of how to select one or more variants from the set of permissible variants and recommend them for implementation (Šubrt et al., 2015). The purpose of the application of MCDM methods is to find the most suitable variant or to make an arrangement of the set of variants. In the case of Good Governance assessment in EU countries, presented in this paper, $28 \mathrm{EU}$ countries are considered as individual variants (set of $p$ variants), and the output is the ranking of these countries from the best to the worst. Variants are assessed on the basis of $k$ criteria (6 aggregate indicators of Good Governance).

There are a variety of multiple criteria techniques to aid selection in conditions of multiple-criteria problems. One of them is the TOPSIS method, where the ranking of variants is based on the relative similarity to the ideal solution. When creating the final order of variants, the TOPSIS method takes into account the distance from the ideal and basal variant and the variability of the values. TOPSIS is considered to be a very useful and informative technique for ranking and selecting variants (Shih et al., 2007; Bhutia and Phipon, 2012). Because of its high flexibility, it is often and widely used in various situations to solve many theoretical and real-world problems (Roszkowska, 2011). For example Dincer (2011) used the TOPSIS method when analysing the EU countries and candidate countries in terms of economic activity in the year 2008. Kuncová (2012) compared by TOPSIS method the EU countries from the e-commerce point of view. Ardielli and Halásková (2015b) used TOPSIS method for assessing of eGovernment in EU countries.

TOPSIS also seems to be a good choice for Good Governance assessment in EU countries. The ranking of countries based on six aggregate indicators by the usage of TOPSIS method is more accurate than simply using averages or additions.

\section{Methods}

TOPSIS method provides a complete arrangement of all variants. Required input data are criteria values for individual variants and weights of individual criteria. The criteria values for the individual variants are arranged in the criterion matrix $Y=\left(y_{i j}\right)$, where $y_{i j}$ is the value of the $i$-th variant evaluated by the $j$-th criterion (Fiala, 2008). It is assumed the maximizing character of criteria.

The method is based on the selection of the variant closest to the ideal variant represented by the vector $\left(H_{1}, H_{2}, \ldots, H_{k}\right)$ and furthest from the basal variant represented by the vector $\left(D_{1}, D_{2}, \ldots, D_{k}\right)$. Application of TOPSIS method is described in Yoon and Hwang (1995):

- Creation of the criteria data matrix $D$.

- Calculation of the normalized data matrix $R=\left(r_{i j}\right)$ according to formula 1:

$$
r_{i j}=\frac{y_{i j}}{\sqrt{\sum_{i=1}^{p} y_{i j}^{2}}}
$$

where $r_{i j}$ are elements of matrix $R ; i=1,2, \ldots p ; j=1,2, \ldots k ; y_{i j}$ are the original input data from data matrix $D$ for variant $i$ and criterion $j ; p$ is the number of variants.

Columns of matrix $R$ are after the normalization the vectors of the unit length according to Euclidean metrics. 
- Calculation of the weight normalized data matrix $W=\left(w_{i j}\right)$ according to formula 2:

$$
\mathrm{w}_{\mathrm{ij}}=\mathrm{v}_{\mathrm{j}} \mathrm{r}_{\mathrm{ij}}
$$

where $w_{i j}$ is weight normalized value and $v_{j}$ is the weight of criterion.

- We will determine the ideal variant $H=\left(H_{l}, H_{2}, \ldots, H_{k}\right)$ and basal variant $\mathrm{D}=\left(D_{l}\right.$, $D_{2}, \ldots, D_{k}$ ), relative to the values of the matrix $W$, see formula 3 and 4 :

$$
\begin{aligned}
H_{j} & =\max \left(w_{i j}\right), \\
D_{j} & =\min \left(w_{i j}\right),
\end{aligned}
$$

for $j=1,2, \ldots k$.

- Distance calculation of variants from the ideal variant, respectively basal variant according to formula 5 and 6 .

$$
\begin{aligned}
& \mathrm{d}_{\mathrm{i}}^{+}=\sqrt{\sum_{\mathrm{j}=1}^{\mathrm{k}}\left(\mathrm{w}_{\mathrm{ij}}-\mathrm{h}_{\mathrm{j}}\right)^{2}} \\
& \mathrm{~d}_{\mathrm{i}}^{-}=\sqrt{\sum_{\mathrm{j}=1}^{\mathrm{k}}\left(\mathrm{w}_{\mathrm{ij}}-\mathrm{d}_{\mathrm{j}}\right)^{2}}
\end{aligned}
$$

for all $i=1,2, \ldots p$

- Calculation of the relative distance indicator of variants $c_{i}$ from basal variant according to formula 7 .

$$
c_{i}=\frac{d_{i}^{-}}{d_{i}^{+}+d_{i}^{-}}
$$

for all $i=1,2, \ldots p$

For values $c_{i}$ apply:

$$
\begin{gathered}
0 \leq c_{i} \leq 1 \\
c_{i}=0<=>a_{i} \approx\left(D_{1}, D_{2}, \ldots, D_{k}\right) \\
c_{i}=1<=>a_{i} \approx\left(H_{1}, H_{2}, \ldots, H_{k}\right)
\end{gathered}
$$

- Arrangement of the variants according to decreasing values of the indicator $c_{i}$, and acquisition of the complete ranking of all variants.

\section{Input Data and Model}

The basis for the evaluation of Good Governance development in EU countries are the data obtained from the database of World Bank, see (World Bank, 2018). There have been monitored six aggregate indicators since 1995. The list of individual indicators and their characteristics are summarized in Table 1. Each of the aggregate indicators becomes normalized values in the interval from -2.5 (worst result) to 2.5 (best result). The values were converted to a percentage for the calculation by TOPSIS method. 


\section{Table 1. Aggregate indicators of Good Governance}

No. Aggregated indicator

Characteristic

\begin{tabular}{|c|c|c|}
\hline \\
\hline$l_{1}$ & Voice and Accountability & $\begin{array}{l}\text { Assesses the extent of democracy on the basis of the characteristics } \\
\text { of the political process, civil liberties, political rights and independ- } \\
\text { ence of the media. }\end{array}$ \\
\hline $\mathrm{I}_{2}$ & $\begin{array}{l}\text { Political Stability and } \\
\text { Absence of Violence }\end{array}$ & $\begin{array}{l}\text { Assesses the probability of destabilizing the authority of a govern- } \\
\text { ment or its overthrow, including the threat of terrorism. }\end{array}$ \\
\hline $\mathrm{I}_{3}$ & $\begin{array}{l}\text { Government Effective- } \\
\text { ness }\end{array}$ & $\begin{array}{l}\text { Government performance is evaluated according to the prerequisites } \\
\text { for formulating and implementing appropriate policies. These as- } \\
\text { sumptions include the provision of quality public services, the quality } \\
\text { of the bureaucracy, the competence of officials, authorities' inde- } \\
\text { pendence from political pressures and the credibility of the govern- } \\
\text { ment in implementing of the proclaimed policies. }\end{array}$ \\
\hline $\mathrm{I}_{4}$ & Regulatory Quality & $\begin{array}{l}\text { Evaluates the policies in terms of interventions distorting markets } \\
\text { functionality and in terms of over-regulation in foreign trade and } \\
\text { business. }\end{array}$ \\
\hline $\mathrm{I}_{5}$ & Rule of Law & $\begin{array}{l}\text { The quality of the legal system is evaluated by the trust in the rules of } \\
\text { society and the degree of respect for them. This indicator expresses } \\
\text { the perception of the incidence of a violent and non-violent crime, the } \\
\text { effectiveness and predictability of court decisions and the enforce- } \\
\text { ment of contracts. }\end{array}$ \\
\hline$I_{6}$ & Control of Corruption & $\begin{array}{l}\text { This indicator measures perceptions of corruption, defined as the use } \\
\text { of public power to obtain a private benefit. }\end{array}$ \\
\hline
\end{tabular}

Source: World Bank (2018).

The model of multi-criteria analysis of variants was created as follows:

- individual variants $a_{i}, i=1, \ldots, p$. These values were represented by individual $28 \mathrm{EU}$ countries.

- individual criteria $f_{j}, j=1, \ldots, k$. These values were represented by 6 aggregate indicators of Good Governance $I_{1}-I_{6}$.

- then the values $y_{i j}$ represents the value of the $i$-th variant evaluated by the $j$-th criterion, $i=1, \ldots, p, j=1, \ldots, k$.

- then the values $v_{j}$, represents the preferences of criteria, $j=1, \ldots, k$.

As stated by Šubrt et al. (2015), when solving a problem, it is very important whether and how one criterion is preferred over another. The criterion preference expresses the importance of this criterion compared to the others. Setting criteria preferences is a difficult task which often depends on the subjective opinion of the decision-maker. In the presented research, the approach of equal preference of all criteria was chosen. That means that all six aggregated indicators of Good Governance $I_{1}-I_{6}$ were seen as criteria with equal preference. Using the TOPSIS method, values of aggregate indicators for individual EU countries in all years of the selected period 2007-2017 were processed, in total 11 calculations. In each year, EU countries were ranked according to the level of Good Governance from the most successful to the least successful. The outputs thus show how individual countries achieved within the EU during the whole selected period. 


\section{Results and interpretations}

The results of the Good Governance development evaluation in EU countries are divided into four parts. First, there was examined the evolution of Governance indicators in the monitored period 2007-2017 in EU countries as average (see Figure 1). Second, the TOPSIS method was applied in each year of the period 2007-2017. The results of individual EU countries were displayed as the ranking of countries (see Figure 2 and 3). Third, the verification of the results was processed by the usage of second MCDM method (see Table 2 and 3). Finally, the classification of country groups was made, and the rankings of individual EU countries in the period 2007 to 2017 were summarized (see Table 4 and 5).

\section{Development of WGI in EU Countries}

To be able to assess the long-term development of governance performance in the EU as a whole, it was necessary to compare the individual indicators over time. Aggregate indicators of individual EU countries (EU-28) were averaged, and their development was captured from 2007 to 2017, see Figure 1. Indicator values were converted from a range of -2.5 to +2.5 to percent values.

Figure 1. Development of Worldwide governance indicators in EU countries (2007-2017)

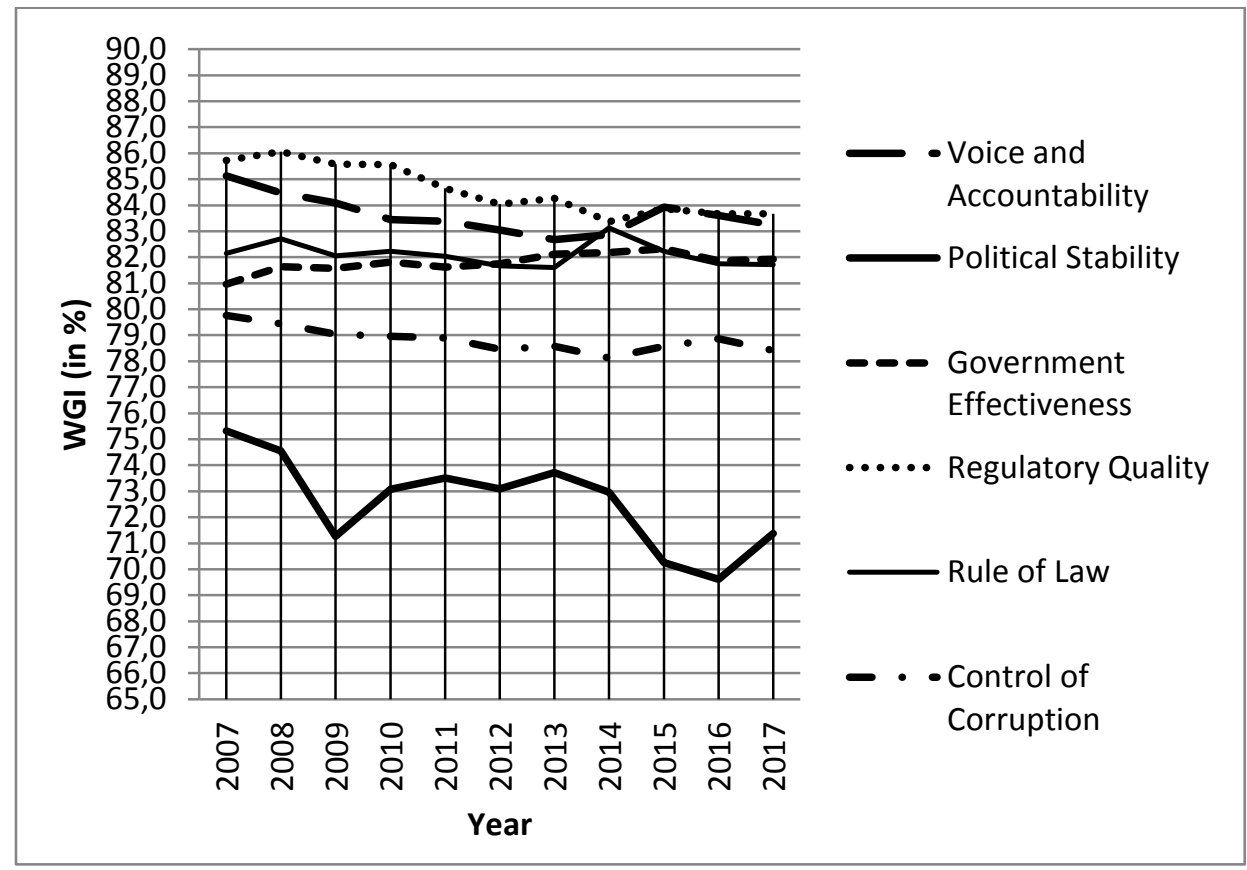

Source: Author's processing according to World Bank (2018)

It is clear from the graph that in the long run, EU countries are best conducting in the area of regulatory quality and voice and accountability. Regulatory quality captures 
perceptions of the ability of the government to formulate and implement sound policies and regulations that permit and promote private sector development. The main variables of this measure in WGI come from: Heritage Foundation Index of Economic Freedom, Economist Intelligence Unit Riskwire \& Democracy Index, World Economic Forum Global Competitiveness Report, Institutional Profiles Database, Political Risk Services International Country Risk Guide and Global Insight Business Conditions and Risk Indicators. The average value of aggregate indicator "regulatory quality" in EU countries reached about $86 \%$ in 2007 and declined slightly in the last decade to about $84 \%$ in 2017. The values of this indicator show that the EU countries, on average, reach very well result in regulatory quality.

Very good results are also evident in the indicator "voice and accountability". Voice and accountability capture perceptions of the extent to which a country's citizens are able to participate in selecting their government, as well as freedom of expression, freedom of association, and free media. The main variables of this measure come from Economist Intelligence Unit Riskwire \& Democracy Index, Freedom House, World Economic Forum Global Competitiveness Report, Gallup World Poll, Institutional Profiles Database, Political Risk Services International Country Risk Guide, Reporters Without Borders Press Freedom Index and Varieties of Democracy Project. The achieved values fluctuated from $85 \%$ in 2007 to $83 \%$ in 2017.

A slightly worse level in EU countries was recorded for indicators "rule of law" and "government effectiveness". The aggregate indicator "rule of law" captures perceptions of the extent to which agents have confidence in and abide by the rules of society, and in particular the quality of contract enforcement, property rights, the police, and the courts, as well as the likelihood of crime and violence. The main variables of this measure come from Economist Intelligence Unit Riskwire \& Democracy Index, World Economic Forum Global Competitiveness Report, Gallup World Poll, Heritage Foundation Index of Economic Freedom, Institutional Profiles Database, Political Risk Services International Country Risk Guide, US State Department Trafficking in People report, Varieties of Democracy Project and Global Insight Business Conditions and Risk Indicators. With slight fluctuations (the year 2008 and 2014), the value of the indicator is around $82 \%$.

The aggregate indicator "government effectiveness" captures perceptions of the quality of public services, the quality of the civil service and the degree of its independence from political pressures, the quality of policy formulation and implementation, and the credibility of the government's commitment to such policies. The main variables of this measure come from Economist Intelligence Unit Riskwire \& Democracy Index, World Economic Forum Global Competitiveness Report, Gallup World Poll, Institutional Profiles Database, Political Risk Services International Country Risk Guide and Global Insight Business Conditions and Risk Indicators. Indicator values in the observed period slightly increased from $81 \%$ in 2007 to $82 \%$ in 2017.

EU countries reach the worst level in indicators „control of corruption“ and ,political stability". The indicator "control of corruption" captures perceptions of the extent to which public power is exercised for private gain, including both petty and grand forms of corruption, as well as "capture" of the state by elites and private interests. The main variables of this measure come from Economist Intelligence Unit Riskwire \& Democra- 
cy Index, World Economic Forum Global Competitiveness Report, Gallup World Poll, Institutional Profiles Database, Political Risk Services International Country Risk Guide, Varieties of Democracy Project and Global Insight Business Conditions and Risk Indicators. During the reference period, the value of the indicator slightly decreased from $80 \%$ in 2007 to $78 \%$ in 2017.

The indicator „,political stability“ and absence of violence/terrorism measures perceptions of the likelihood of political instability and/or politically-motivated violence, including terrorism. The main variables of this measure come from Economist Intelligence Unit Riskwire \& Democracy Index, World Economic Forum Global Competitiveness Report, Cingranelli Richards Human Rights Database and Political Terror Scale, iJET Country Security Risk Ratings, Institutional Profiles Database, Political Risk Services International Country Risk Guide and Global Insight Business Conditions and Risk Indicators. During the reference period, the value of the indicator decreased from $75 \%$ in 2007 to $71 \%$ in 2017.

\section{Evaluation of Good Governance in EU countries by Usage of TOPSIS}

Good Governance performance in EU countries in the period 2007-2017 was evaluated by the usage of TOPSIS method. The results in individual years were ordered according to the value of relative distance indicator $c_{i}$. In this article are presented in detail only the results of the year 2007 and 2017. In Figure 2, there are summarized the ranking of EU countries according to the level of Good Governance from the best to the worst. In the year 2007, the best five positions occupied Finland, Sweden, Austria, Denmark, and Luxembourg. On the worst five positions placed Poland, Italy, Croatia, Bulgaria, and Romania.

Figure 2. The evaluation of EU countries according to the level of Good Governance in 2007

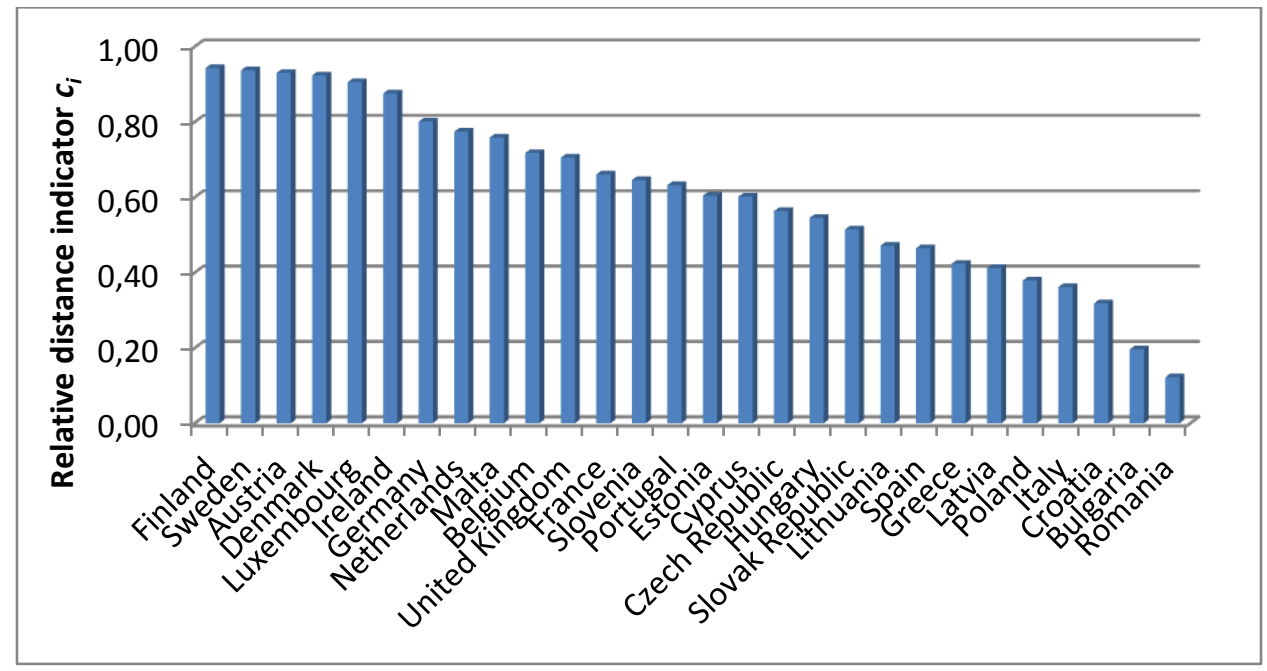

Source: Author's processing 
In the monitored period 2007-2017 the situation was changing only slightly on the top positions. The best positions occupied mainly Finland, Luxembourg, Austria, or Sweden. On the worst positions shifted Croatia, Bulgaria, Greece, and Romania.

For the purpose of ranking comparison at the end of the selected period, the detailed results of the year 2017 are presented, see Figure 3. The ranking of countries differs slightly on the five best positions. The top positions are occupied by Luxembourg, Finland, Sweden, Netherlands, and Austria. Also, the worst five positions differ slightly; they are occupied by Croatia, Italy, Bulgaria, Greece, and Romania.

Figure 3. The evaluation of EU countries according to the level of Good Governance in 2017

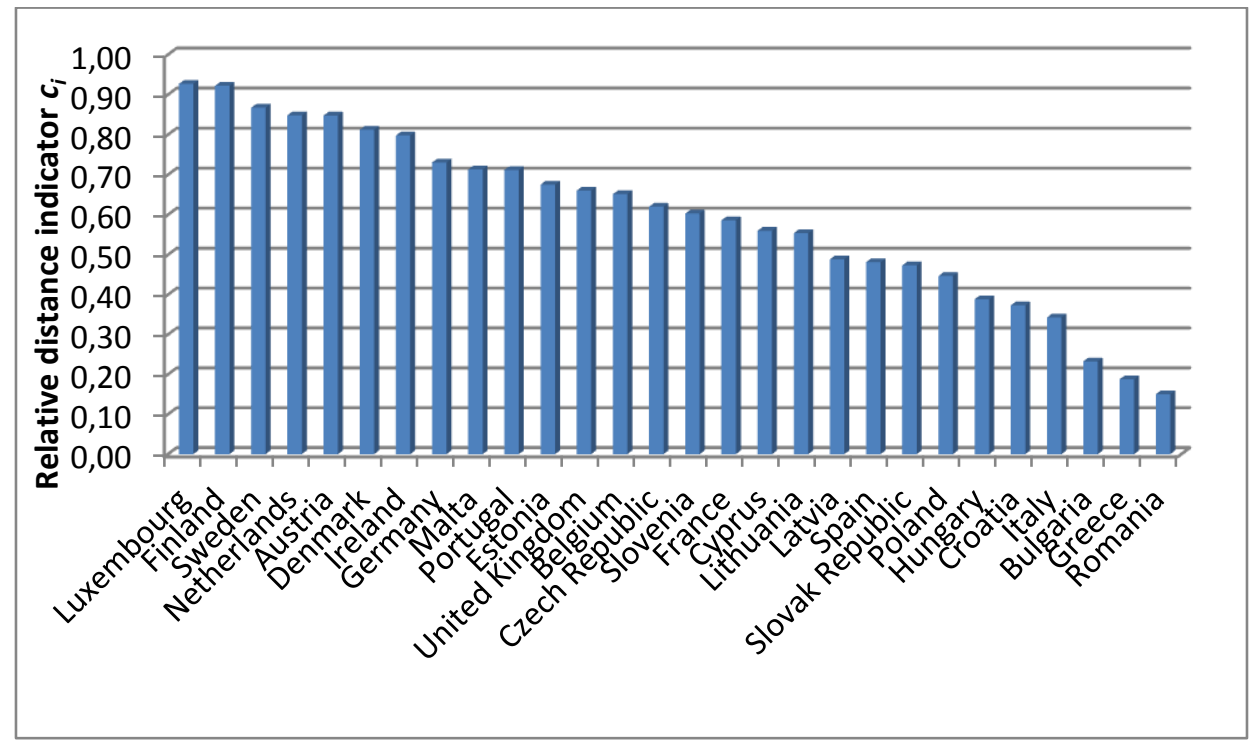

Source: Author's processing

\section{Verification of the Results by Usage of WSA Method}

When using MCDM methods, it is always advisable to verify the sensitivity of the results by applying yet another method. The verification of the results in the year 2007 and 2017 was processed by second MCDM method. As the appropriate method was chosen Weighted Sum Approach (WSA). WSA method is based on the principle of utility maximization. It arranges the variants in the order according to the total utility, which is taking into account all represented criteria, see more Fiala (2008). In Table 2 and 3 , there are displayed the results of both methods. 
Table 2. Verification of the final result (2007)

\begin{tabular}{llllll} 
Country & TOPSIS & WSA & Country & TOPSIS & WSA \\
\hline Austria & 3 & 4 & Italy & 25 & 24 \\
Belgium & 10 & 10 & Latvia & 23 & 23 \\
Bulgaria & 27 & 27 & Lithuania & 20 & 21 \\
Croatia & 26 & 26 & Luxembourg & 5 & 5 \\
Cyprus & 16 & 13 & Malta & 9 & 11 \\
Czech Republic & 17 & 19 & Netherlands & 8 & 7 \\
Denmark & 4 & 1 & Poland & 24 & 25 \\
Estonia & 15 & 15 & Portugal & 14 & 14 \\
Finland & 1 & 2 & Romania & 28 & 28 \\
France & 12 & 12 & Slovakia & 19 & 20 \\
Germany & 7 & 8 & Slovenia & 13 & 16 \\
Greece & 22 & 22 & Spain & 21 & 17 \\
Hungary & 18 & 18 & Sweden & 2 & 3 \\
Ireland & 6 & 6 & United Kingdom & 11 & 9 \\
\hline
\end{tabular}

Source: Author's processing

Table 3. Verification of the final result (2017)

\begin{tabular}{llllll} 
Country & TOPSIS & WSA & Country & TOPSIS & WSA \\
\hline Austria & 5 & 6 & Italy & 25 & 23 \\
Belgium & 13 & 12 & Latvia & 19 & 20 \\
Bulgaria & 26 & 26 & Lithuania & 18 & 18 \\
Croatia & 24 & 25 & Luxembourg & 1 & 3 \\
Cyprus & 17 & 17 & Malta & 9 & 11 \\
Czech Republic & 14 & 15 & Netherlands & 4 & 4 \\
Denmark & 6 & 5 & Poland & 22 & 22 \\
Estonia & 11 & 10 & Portugal & 10 & 13 \\
Finland & 2 & 1 & Romania & 28 & 27 \\
France & 16 & 14 & Slovakia & 21 & 21 \\
Germany & 8 & 7 & Slovenia & 15 & 16 \\
Greece & 27 & 28 & Spain & 20 & 19 \\
Hungary & 23 & 24 & Sweden & 3 & 2 \\
Ireland & 7 & 8 & United Kingdom & 12 & 9 \\
\hline Source: & & & & &
\end{tabular}

Source: Author's processing 
Also the TOPSIS results of the year 2017 were confirmed by the usage of WSA method. However, the results are slightly different. On the best five positions processed by WSA are from top Finland (2nd position by TOPSIS), Sweden ( $3 \mathrm{rd}$ position by TOPSIS), Luxembourg (3rd position by TOPSIS), Netherlands (4th position by TOPSIS as well) and Denmark (6th position by TOPSIS). On the worst positions placed similarly Hungary, Croatia, Bulgaria, Romania, and Greece. The reason for the differences lies in the diverse computing algorithm. Moreover, TOPSIS method takes into account the range of values of the criterion and does not favour extreme values as WSA.

\section{Classification of Country Groups and the Final Ranking}

Based on the $c_{i}$ values from the year 2017, the EU countries were divided into four groups by usage of hierarchical clustering, Ward's method, see Table 4. Hierarchical cluster analysis was performed in the IBM SPSS software. The purpose of the clustering was to create the groups of EU countries based on the level of Good Governance and to identify which countries are performing well, which are performing satisfactorily and which are performing insufficiently.

Table 4. Clustering of EU countries according to the level of Good Governance (2017)

\begin{tabular}{llll} 
Leading countries & $\begin{array}{l}\text { Well-performing coun- } \\
\text { tries }\end{array}$ & $\begin{array}{l}\text { Low-performing } \\
\text { countries }\end{array}$ & Lagging countries \\
\hline Austria (AT), & Belgium (BE), & Croatia (HR), & Bulgaria (BG), \\
Denmark (DK), & Cyprus (CY), & Hungary (HU), & Greece (EL), \\
Finland (FI), & Czech Republic (CZ), & Italy (IT), & Romania (RO). \\
Ireland (IE), & Estonia (EE), & Latvia (LV), & \\
Luxembourg (LU), & France (FR), & Poland (PL), & \\
Netherlands (NL), & Germany (DE), & Spain (ES), \\
Sweden (SE). & Lithuania (LT). & Slovakia (SK). & \\
& Malta (MT), & & \\
& Portugal (PT), & & \\
& Slovenia (SI), & & \\
& United Kingdom (UK). &
\end{tabular}

Source: Author's processing

In Table 4, there are listed four categories of countries based on the results of hierarchical cluster analyses. In the first category are included EU countries with the best results of Good Governance level. There are the Scandinavian countries - Denmark, Finland, Sweden - and Luxembourg, Austria, Netherlands, and Ireland. These countries belong to countries with advanced, well-functioning, and effective public administration. Not surprisingly, they have a high level of Good Governance as well. Category 2 contains EU countries with still good performance in Good Governance. This group includes both the founding countries of the EU (Germany, France) and highly developed economies (United Kingdom) as well as the less developed countries EU acceded later as Estonia, Czech Republic or Cyprus. These are countries that have shown minor and moderate weaknesses in Good Governance indicators. In the case of Germany, Great Britain, France, and Austria, the rating was reduced due to the threat of terrorism. In the case of the Czech Republic or Lithuania major weaknesses in the area of corruption were reported. EU countries presented in category 3 are the countries with belowaverage results. Spain and Italy reported bad values in the terrorist threat and corruption. 
Slovakia showed a high level of corruption, as well as Hungary, Latvia, and Croatia. Poland, Italy, and Croatia showed additionally the poor quality of the legal system. Category 4 lists EU countries with the worst level of Good Governance. In the case of Bulgaria, Greece and Romania were identified great shortcomings in the area of corruption, quality of law, and effectiveness of the public sector.

Although the ranking of EU countries varies in individual years, it is possible to notice that the best and worst positions are constantly rotated by the same countries. Therefore, a comparison of the development of the EU countries' rankings in individual years was created, see Table 5. The top five countries and the worst five countries are highlighted in colour.

Table 5. Ranking of EU countries in the years 2007 - 2017

\begin{tabular}{|c|c|c|c|c|c|c|c|c|c|c|c|}
\hline & 2007 & 2008 & 2009 & 2010 & 2011 & 2012 & 2013 & 2014 & 2015 & 2016 & 2017 \\
\hline AT & 3 & 3 & 5 & 5 & 6 & 5 & 5 & 5 & 3 & 6 & 5 \\
\hline $\mathrm{BE}$ & 10 & 10 & 9 & 9 & 8 & 8 & 8 & 10 & 11 & 13 & 13 \\
\hline$B G$ & 27 & 27 & 27 & 27 & 27 & 26 & 28 & 28 & 28 & 27 & 26 \\
\hline $\mathrm{HR}$ & 26 & 26 & 24 & 25 & 25 & 25 & 25 & 24 & 24 & 24 & 24 \\
\hline$C Y$ & 16 & 15 & 17 & 15 & 16 & 13 & 15 & 17 & 19 & 18 & 17 \\
\hline$C Z$ & 17 & 17 & 15 & 17 & 14 & 17 & 16 & 14 & 14 & 15 & 14 \\
\hline DK & 4 & 5 & 4 & 4 & 5 & 6 & 6 & 7 & 6 & 5 & 6 \\
\hline EE & 15 & 16 & 16 & 14 & 13 & 14 & 13 & 11 & 13 & 10 & 11 \\
\hline $\mathrm{FI}$ & 1 & 1 & 1 & 1 & 1 & 1 & 1 & 1 & 2 & 3 & 2 \\
\hline FR & 12 & 14 & 12 & 11 & 12 & 12 & 12 & 13 & 16 & 17 & 16 \\
\hline $\mathrm{DE}$ & 7 & 8 & 8 & 8 & 9 & 9 & 7 & 8 & 8 & 8 & 8 \\
\hline EL & 22 & 24 & 26 & 26 & 26 & 27 & 26 & 26 & 27 & 28 & 27 \\
\hline $\mathrm{HU}$ & 18 & 19 & 21 & 21 & 21 & 22 & 23 & 23 & 23 & 25 & 23 \\
\hline IE & 6 & 6 & 7 & 7 & 7 & 7 & 9 & 6 & 7 & 7 & 7 \\
\hline IT & 25 & 23 & 25 & 24 & 24 & 24 & 24 & 25 & 25 & 23 & 25 \\
\hline LV & 23 & 25 & 23 & 23 & 23 & 23 & 22 & 21 & 22 & 21 & 19 \\
\hline LT & 20 & 21 & 20 & 20 & 22 & 20 & 19 & 19 & 17 & 16 & 18 \\
\hline LU & 5 & 2 & 2 & 2 & 2 & 2 & 2 & 2 & 1 & 1 & 1 \\
\hline MT & 9 & 9 & 10 & 10 & 10 & 10 & 10 & 9 & 10 & 9 & 9 \\
\hline $\mathrm{NL}$ & 8 & 7 & 6 & 6 & 4 & 4 & 4 & 4 & 5 & 4 & 4 \\
\hline PL & 24 & 20 & 18 & 18 & 18 & 18 & 18 & 18 & 18 & 22 & 22 \\
\hline PT & 14 & 12 & 13 & 16 & 17 & 15 & 14 & 15 & 12 & 12 & 10 \\
\hline RO & 28 & 28 & 28 & 28 & 28 & 28 & 27 & 27 & 26 & 26 & 28 \\
\hline SK & 19 & 18 & 19 & 19 & 20 & 19 & 20 & 20 & 21 & 20 & 21 \\
\hline SI & 13 & 11 & 11 & 13 & 15 & 16 & 17 & 16 & 15 & 14 & 15 \\
\hline ES & 21 & 22 & 22 & 22 & 19 & 21 & 21 & 22 & 20 & 19 & 20 \\
\hline SE & 2 & 4 & 3 & 3 & 3 & 3 & 3 & 3 & 4 & 2 & 3 \\
\hline UK & 11 & 13 & 14 & 12 & 11 & 11 & 11 & 12 & 9 & 11 & 12 \\
\hline
\end{tabular}

Source: Author's processing. 
There is a clear view of the development of the EU countries' rankings over the reporting period. The top positions are steadily occupied by Finland, Sweden, and Luxembourg. Good results are also achieved by Austria, Netherlands, and Denmark. These countries are the most advanced in public administration across EU countries and are on the top in Good Governance worldwide also. Significant positive developments in governance performance over the period were recorded by the Netherlands and Estonia. The Netherlands moved from the 8th position in 2007 to 4th position in 2017 and Estonia from 15 th position to 11 th position. Also, Latvia moved significantly from $23 \mathrm{rd}$ position in 2007 to 19 th position in 2017 . This positive development may be due to the development of eGovernment and eServices in these countries and an emphasis on open public administration. On the contrary, the negative developments have been noted by Belgium (from 10th position in 2007 to 13th. position in 2017), France (from 12th position in 2007 to 16 th position in 2017), Greece (from 22nd position in 2007 to 27 th position in 2017), and Hungary (from 18. position in 2007 to 23rd position in 2017). Deterioration in these countries is likely to be mainly due to decreased security because of the threat of terrorism. Steadily worst-rated countries include Croatia, Italy, Romania, Greece, and Bulgaria. These countries generally show the poor performance of public administration across EU countries. Interesting is the position of the Czech Republic. It was found out that it is on average among EU countries in the last decade (ranging from 17th - 14th position), however in the last five years we can see the position improvement (always 14th or 15th position) although there was no real improvement in all indicators in the last five years.

\section{Discussion}

Good Governance means the attainment of ideals of democracy and participation of people in all activities of the state. It is currently a great subject in all countries of the world. Ewadlt (2001) says that Good Governance is directly related to both public administration processes as well as the essential ingredients of accountability, democracy, ethics, rule of law and transparency. The World Bank is attempting to measure governance performance with six aggregated indicators covering the areas above. Some authors criticize this approach, for example Andrew (2008) questions the validity of definitions of Good Governance indicators and their relationship to the reality of their effectiveness. Although the indicators are commonly used to compare countries and developments in individual years in various scientific papers. The approach of data processing by different authors differ, however. Some use averaging (Žák, 2005; Ardielli, 2016), others add up (Madzova, Sajnoski, and Davcev, 2013). In the presented article, there was created the ranking of EU countries according to the level of Good Governance by the usage of TOPSIS method.

Creation of the ranking of countries is often used in the reports dealing with the performance of economic sectors and other branches. For example, on the World Bank pages we can see the ranking of countries according to the WGI, on United Nations pages is presented the ranking of countries according to the eGovernment Development Index (EDGI) or eParticipation Index (EPI), see UNPACS (2018), in European Commission (2018) are the EU countries ranked according to the performance of public administration. Scientific work is also dealing with this issue, see Kuncová (2012) or Charron, Dijkstra, and Lapuente (2015). 
In the presented research has been confirmed the excellent position of the Nordic countries' across EU countries in the area of Good Governance. Denmark, Finland, Sweden, and also Luxembourg and Netherlands - these countries have been long-term among the top 10 countries in the world with the best Good Governance. Switzerland, New Zeeland, Canada, and Australia are also the world leaders in this area. The countries placed well in Good Governance rankings are mainly well placed also in the rankings of eGovernment implementation. Denmark, Finland, Sweden, Luxembourg, and the Netherlands are in the top 20 world leaders in eGovernment development, see UNPACS (2018). These countries were ranked on the best positions also in the assessment of public administration capacity and performance of the EU countries by the European Commission in the year 2018. The first five positions occupied Denmark, Finland, Sweden, Netherlands, and the United Kingdom. On the last five positions placed Romania, Greece, Croatia, and Bulgaria and Slovakia (European Commission, 2018).

Greece, Romania, and Bulgaria ranked worst also in the research presented in this article. This is inconsistent with the European Commission (2018). Although these countries are the worst performers within the EU countries, their results are average in terms of global outcomes. For example, the lowest level of Good Governance has been recorded in some member countries of the Council of Europe - in Albania, Serbia, Macedonia or Bosnia and Herzegovina, see Ardielli (2016) or similarly also in analyse of West Balkans countries in Madzova, Sajnoski and Davcev (2013).

As appears from the contemporary praxes, a central goal of reforms in many less successful EU countries is achieving transparency. As stated by Ladi and Ruso-Dragoumis (2007) to achieve transparency and to apply the values of Good Governance, an effective institutional framework must be applied, the participation of citizens in governance should be enhanced, and an effective system of internal and external control needs to be developed. A further tool for strengthening transparency and openness in the public sector and for combatting corruption is the use of information technologies at all levels of public administration and the implementation of eGovernment (Máchová, Volejníková, and Lněnička, 2018). It can improve the services provided to the citizens as well as the smooth functioning of democracy (Ladi and Ruso-Dragoumis, 2007).

When comparing the results obtained by averaging (Ardielli, 2016) and TOPSIS method, the ranking of countries performed by usage of TOPSIS is more accurate. The advantages of TOPSIS methods is that it takes into account the variability and the distance from the ideal and basal variant. The advantages of TOPSIS compared to other MCDM methods are its simplicity, good computational efficiency, and the ability to measure the relative performance for each variant in a simple mathematical form. As stated by Rozskowska (2011), the concept of the TOPSIS method is clear, the calculation is simple and convenient, and the methodology can be extended and adjusted to specific environments.

\section{Conclusion}

In the presented article, there was offered the option of processing the data of the World Bank (aggregate indicators of Good Governance - WGI) by the usage of MCDM methods, namely the TOPSIS method. Multi-criteria analysis of variants allowed the evalua- 
tion of all EU countries (variants) according to the 6 given criteria (aggregate indicators).

In the first part of the research, there were conducted the averages of these aggregated indicators for the 28 European Union member countries in the period 2007-2017. The values of these indicators in the EU are above-average in the long-term relative to the global average and in comparison with developing countries. However, we can see the decrease in almost all monitored indicators during the selected period. The slight increase is evident only in the indicator "government effectiveness".

In the second part of the research, the TOPSIS method was applied. By usage of this method, the sorting of variants according to defined criteria was performed. As a result, countries were ranked according to the Good Governance performance and the development in the individual years of the monitored period was recorded. It was found, that the most successful EU countries in the area of Good Governance are Scandinavian countries (Finland, Sweden, and Denmark), Luxembourg, Austria, and the Netherlands. On the contrary, the worst-performing EU countries are Bulgaria, Romania, and Greece.

In the third part of the research, the results of TOPSIS method were verified by the usage of WSA method. Using this method, similar results have been achieved as with the application of the TOPSIS method. In the year 2017, by the usage of WSA method, on the first three positions placed Luxembourg (1st position), Finland (2nd position), Sweden (3rd position). By usage of TOPSIS method, the same countries were confirmed in a slightly different order - Luxembourg (3rd position), Finland (1st. position), Sweden (2nd position). A similar situation has occurred in the case of worst-performing countries. By usage of TOPSIS method was found out the following order - Bulgaria (26th position), Romania (27th position), Greece (28th position). By usage of WSA method were confirmed the same countries with positions - Bulgaria (26th position), Romania (28th position), Greece (27th position). Similar results were also found in other years.

In the fourth part of the research, the clustering of EU countries according to the level of Good Governance was performed. This way four country groups with similar results were identified - leading countries, well-performing countries, low-performing countries and lagging countries. Last, the final overview of the placement of individual EU countries in the period 2007-2017 was accomplished. There is showed which countries have long-term high levels of monitored indicators and which, on the contrary, are lagging behind in this area.

Based on the results achieved TOPSIS method acknowledged as a suitable tool for evaluation of Good Governance by the usage of WGI monitored by the World Bank. TOPSIS takes into account the variability of data and is thus more accurate when creating the ranking of countries than mere averaging or adding of indicators to the overall indicator.

Funding: The paper was created within the financial support of the student grant project SGS No. SP2017/129 "Economic Factors Affecting the Ensuring of Public Services with Collective Consumption" on Faculty of Economics, Technical University of Ostrava. 
Disclosure statement: No potential conflict of interest was reported by the author.

\section{References}

ABDELATIFF, A.M. (2003). Good Governance and its relationship to democracy and economic development, [online]. 2003 [cit. 2019-07-22]. Available at: ftp://pogar.org/LocalUser/pogarp/governance/aa/goodgov.pdf

ACEMOGLU, D., ROBINSON, J. (2010). Why Nations Fail: The Origins of Power, Prosperity, and Power. New York: Crown Business.

AGERE, S. (2000). Promoting Good Governance: Principles, Practices and Perspectives, Managing the Public Service: Strategies for Improvement, No. 11, [online]. Commonwealth Secretariat, London. 2000 [cit. 2019-06-02]. DOI: $\underline{10.14217 / 9781848597129-e n}$

ANDREWS, M. (2008). The Good Governance Agenda: Beyond Indicators without Theory. Oxford Development Studies, Vol. 36, No. 4, pp. 379-423. DOI: $\underline{10.1080 / 13600810802455120}$

ARDIELLI, E. (2016). Implementation of Good Governance Concept in the European Union Member Countries. In ICEI 2016. Ostrava: VŠB-TUO, pp. 28- 36.

ARDIELLI, E., HALÁSKOVÁ, M. (2015a). Evaluation of Good Governance in EU countries. Acta academica karviniensia. Vol. 15, No. 3, pp. 5-17. DOI: $\underline{10.25142 / \mathrm{aak} .2015 .027}$

ARDIELLI, E., HALÁSKOVÁ, M. (2015b). Assessment of E-government in EU countries. Scientific Papers of the University of Pardubice. Vol. 22, No. 34, pp. 4-16.

BHUTIA, P. W., PHIPON, R. (2012) Application of AHP and TOPSIS Method for Supplier Selection Problem, Journal of Engineering, Vol. 2., No. 10, pp. 43-50.

CHARRON, N., DIJKSTRA, L. and V. LAPUENTE. (2015). Mapping the Regional Divide in Europe: A Measure for Assessing Quality of Government in 206 European Regions. Social Indicators Research. Vol. 122, No. 2, pp. 315-346. DOI: 10.1007/s11205-014-0702-y

CLAGUE, C. et al. (1999). Contract-intensive money: Contract enforcement, property rights, and economic performance. Journal of Economic Growth, Vol. 4, No. 2, pp. 185211. DOI: $10.1023 / \mathrm{A}: 1009854405184$

COUNCIL OF EUROPE, 2007. Recommendation CM/Rec(2007)7 of the Committee of Ministers to member states on good administration. [online]. 2015 [cit. 2019-02-22] Available at: https://wcd.coe.int/ViewDoc.jsp?id=1155877.

COURT, J., HYDEN, G. (2003). World Governance Survey: a New Approach to Assessing Governance. Global Corruption Report 2003. [online]. 2003. [cit. 2019-02-12]. Available at: http://publication.fsv.cuni.cz/attachments/121_018_Nekola.pdf.

DINCER, S. E. (2011). Multi-Criteria Analysis of Economic Activity for European Union Member States and Candidate Countries: TOPSIS and WSA Applications. European Journal of Social Sciences. Vol. 21, No. 4, pp. 563-572. 
EUROPEAN COMMISSION (2018). A comparative overview of public administration characteristics and performance in EU28 [online]. Luxembourg: Publications Office of the European Union, 2018 [cit. 2019- 08-08]. Available at: https://publications.europa.eu/en/publication-detail/-/publication/3e89d981-48fc-11e8be1d-01aa75ed71a1/language-en

EWALDT, J.A.G. 2001. Theories of Governance and New Public Management. [online]. 2001 [cit. 2019- 07-06]. Available at: http://unpan1.un.org/intradoc/groups/public/documents/ASPA/UNPAN000563.pdf

FIALA, P. (2008). Modely a metody rozhodování. Praha: Oeconomica.

GRINDLE, M.S. (2004). Good enough governance: Poverty reduction and freeform in developing countries. An International Journal of Policy, Administration and Institutions, Vol. 17, pp. 525-548. DOI: 10.1111/j.0952-1895.2004.00256.x

GRINDLE, M.S. (2007). Good Enough Governance Revisited. Development Policy Review, Vol. 25, No. 5, pp. 553-574. DOI: 10.1111/j.1467-7679.2007.00385.X

HALDENWANG, C.V. (2004). Electronic government (E-Government) and development. The European Journal of Development Research. Vol.16, pp. 417-432.

JANN, W., RÖBER, M, and H. WOLLMANN. (2006). Public management - Grundlagen, Wirkungen, Kritik. Berlin: Sigma.

JONES, L.R., KETTL, D.F. (2003). Assessing public financial management reform in international context. International Public Management Review, Vol.4, pp. 1-16.

KAUFMANN, D., KRAAY, A. and M. MASTRUZZI. (2010). The Worldwide Governance Indicators: Methodology and Analytical Issues [online]. World Bank Policy Research Working Paper No. 5430, 2010 [cit. 2019- 07-06]. Available at: https://ssrn.com/abstract=1682130

KEPING, Y. F. (2018). Governance and Good Governance: A New Framework for Political Analysis. Journal of the Humanities and Social Sciences. Vol. 11, No.1. pp. 18.

KLENK, T., NULLMEIER, F. (2004). Public Governance als Reforms Strategie. Düsseldorf: Edition der Hans-Böckler-Stiftung.

KLIMOVSKÝ, D. (2010). Genéza koncepcie good governance a jej kritické prehodnotenie $\mathrm{v}$ teoretickej perspektíve. Ekonomický časopis/Journal of Economics. Vol. 58, No.2, pp. 188-205.

KOOIMAN, J. (2003). Governing as Governance. London: Sage.

KUNCOVÁ, M. (2012). Elektronické obchodování - srovnání zemí EU v letech 20082009 s využitím metod vícekriteriálního hodnocení variant. In: IRCINGOVÁ, J., TLUČHOǨ, J., Trendy v podnikání 2012. Plzeň: ZČU, pp. 1-9.

LADI, S., RUSO-DRAGOUMIS, E. (2007). Study on Institutional Renewal and Good Governance in BSEC Member States. Athens: International Centre for Black Sea Studies. 
MADZOVA, V., SAJNOSKI, K. and L. DAVCEV. (2013). E-Government as an Efficient Tool towards Good Governance. Balkan Social Science Review. Vol. 1, pp. 157174.

NORTH, C. D. (1991). Institutions, Institutional Change and Economic Performance. Cambridge: Cambridge University press.

POTU゚ČEK, M. et al. (2007). Strategické vládnutí a Česká republika. Praha: Grada, a.s.

POTĚŠIL, L. (2008). Good Administration in Scope of the Council of Europe. Veřejná správa. Vol. 12, pp. VII - VIII.

PILLAY, P. (2016). The relationship between public administration and good governance: the case of South Africa. African Journal of Public Affairs, Vol. 1, pp 18-31.

ROSZKOWSKA, E. (2011). Multi-criteria Decision Making Models by Applying the Topsis Method to Crisp and Interval Data. Multiple Criteria Decision Making. Vol. 6, pp. 200-230.

SHIH, H., SHYUR, H. and E.S. LEE. (2007). An extension of TOPSIS for group decision making, Mathematical and Computer Modelling, Vol. 45, No. 7-8, pp. 801-813. DOI: $\underline{\text { 10.1016/j.mcm.2006.03.023 }}$

SUNDARAM, J. K. (2018). Does good governance always boost development? [online]. World Economic Forum. 2018. [cit. 2018- 08-08]. Available at: https://www.weforum.org/agenda/2015/06/does-good-governance-always-boostdevelopment/

ŠUBRT, T. et al. (2015). Ekonomicko-matematické metody. Plzeň: Aleš Čeněk, s.r.o.

UNPACS. (2018). Data Center - Government Development Index. [online]. 2018. [cit. 2018- 10-02]. Available at: http://unpan3.un.org/egovkb/en-us/Data-Center.

WORLD BANK. (1992). Governance and development (English). Washington, DC : The World Bank.

WORLD BANK. (2018). Worldwide Governance Indicators. [online]. 2018. [cit. 2018- 18-10]. Available at: http://info.worldbank.org/governance/wgi/\#doc

YOON, K. P., HWANG, CH. (1995). Multiple Attribute Decision Making: An Introduction. California: Sage.

ZANGER, S. C. (2000). Good Governance and European Aid the Impact of Political Conditionality. European Union Politics. Vol. 1, No.3, pp. 293-317. DOI: $10.1177 / 1465116500001003002$

ŽÁK, M. (2005). Kvalita správy: hodnocení a měření [online]. 2005 [cit. 2018- 11-12]. Available at: paper/gf_WPNo13.pdf

https://www.vsem.cz/data/data/ces-soubory/working- 